\title{
Production of Akoya pearls from the Southwest coast of India
}

\author{
V. Kripa ${ }^{1}$, K.S. Mohamed *, K.K. Appukuttan, T.S. Velayudhan \\ Central Marine Fisheries Research Institute, P.O. Box 1603, Cochin 682018, Kerala State, India
}

Received 12 December 2005; received in revised form 21 September 2006; accepted 27 September 2006

\begin{abstract}
The Indian pearl oyster Pinctada fucata (Gould) is typically capable of producing pearls of 3-5 mm diameter. The feasibility of production of pearls similar to Akoya pearls of 6-8 $\mathrm{mm}$ diameter was studied from the southwest coast of India. Along with this, mortality and retention rates of implanted oysters, rate of nacre production, thickness of nacre deposited, quality and type of pearls produced and effect of hydrographic variations on the mortality of implanted oysters were also studied. A total of 706 oysters were implanted, 311 with $5 \mathrm{~mm}, 395$ with $6 \mathrm{~mm}$ nuclei and stocked in 30 cages for a period of 317 days. The mortality rates were highest, $0.173 \pm 0.22$ for the $6 \mathrm{~mm}$ nucleus implanted oysters followed by $5 \mathrm{~mm}$ nucleus implanted oysters at $0.107 \pm 0.025$ during the first 30 days after implantation. These rates were significantly different $(P<0.05)$ from the mortality rate of the control oysters $(0.042 \pm 0.04)$. The retention rates based on the surviving oysters, ranged from 33 to $61 \%$ (average 45.9 for $5 \mathrm{~mm}$ ) and 31 to $60 \%$ (average $48.9 \%$ for $6 \mathrm{~mm}$ ). The nacre deposition rates on the nuclei were found to be $4.0 \pm 1.0 \mu \mathrm{m}_{\text {day }}{ }^{-1}$ and $3.0 \pm 1.0 \mu \mathrm{m}^{-1} \mathrm{day}^{-1}$ for 6 and $5 \mathrm{~mm}$ nuclei respectively. Of the total 131 pearls obtained, 27.6\% were A-grade, 31.3\% B-grade, 19.8\% C-grade, $7.6 \%$ baroques and $13.7 \%$ rejects or trash. The total suspended solids (TSS) in the water were found to be positively correlated $(P<0.05)$ with the monthly mortality rate of the implanted oysters. The study showed that it was possible to obtain relatively thick nacre within a short period of 10 months, the deposition rate being about 9 times higher than that observed in Japanese waters and 2.2 to 2.3 times more than that along the Indian southeast coast.
\end{abstract}

(C) 2006 Elsevier B.V. All rights reserved.

Keywords: Pinctada fucata; 6-8 mm Akoya pearl; Mortality rates; Retention rates

\section{Introduction}

Pearls produced in the pearl oyster Pinctada fucata, (Gould) one of the smallest among pearl producing bivalves, are popularly known as the Akoya pearls, and these are superior to freshwater pearls but less valuable than the larger Tahitian or South Sea pearls. Akoya

\footnotetext{
* Corresponding author. Tel.: +91 484 2394867; fax: +91 484 2394909.

E-mail address: ksmohamed@vsnl.com (K.S. Mohamed).

${ }^{1}$ Present Address: Research Centre of CMFRI, West Hill, Calicut 673005, Kerala State, India.
}

pearls are, by far, the most fashionable pearls used in necklaces especially the 14 to 16 -inch choker and the 17 to 19-inch princess, the two most popular jewelry pieces. Akoya pearls generally have a diameter ranging from 3 to $10 \mathrm{~mm}$ and its value increases with diameter.

Considerable research has been done on various aspects of $P$. fucata such as growth, seed production, fouling, nacre production and inheritance of shell characters (Shirai, 1970; Alagarswami, 1991; Gervis and Sims, 1992; Velayudhan et al., 1996; Wada and Kamaru, 1996). In India, pearl research and development have been focused on the production of small pearls of diameter less than $5 \mathrm{~mm}$ and during the past three 
decades several important aspects such as retention rates of implanted nuclei and the production levels have been studied. The pearl retention rates and mortality of the implanted oysters have been found to vary depending on the location of the farm site (Alagarswami, 1991; Victor et al., 2003) and diameter of nucleus (Dharmaraj and Sukumaran, 2003a,b). The use of larger nuclei decreases the pearl yield from 70 to $40 \%$ in Akoya oysters in Japan (Shirai, 1970). Jagadis et al. (2003) found retention rates and survival to vary with depth at which the farms are located in the Gulf of Mannar. Alagarswami (1991) reported that the number of nuclei implanted within an oyster is also important and retention rates vary for single and multiple implantations. In Pinctada martensii, the major species in the marine pearl industry in China, double implantation is commonly practiced and the recovery rate is $50 \%$ (Guo et al., 1999). There are however, no specific studies on retention rates for implantations of nuclei above $6 \mathrm{~mm}$ in P. fucata.

The financial success of a pearl culture enterprise depends on the percentage of quality pearls produced (Alagarswami, 1991) and significant variations in production rates and quality of pearls produced have been observed in the experimental and commercial pearl farms in India (James and Narasimham, 1994; Victor et al., 2003). Such inconsistency has been reported for Akoya pearls as well as black pearls (Alagarswami, 1991; Norton et al., 1996) and several reasons have also been attributed to such variations (Norton et al., 2000). Concern regarding the high mortalities following round pearl operation and the over-production of poor quality pearls has been expressed (Wada, 1991) and efforts have also been made in the recent years to overcome the shortfalls and improve the efficiency of marine pearl production techniques (Norton et al., 1996, 2000). In general, it has been observed that for every 100 oysters operated on, approximately one-third will die, one-third will reject the shell bead and the remaining one-third will produce mostly poor quality pearls. Only about $5 \%$ will be gem-quality pearls (Norton et al., 1996).

Apart from the technical shortfalls, the environment in which the implanted oysters are farmed also affect oyster mortality and pearl quality (Gervis and Sims, 1992). Deposition of nacre is largely influenced by the temperature of the seawater, with higher temperatures accelerating nacre deposition and lower temperatures decreasing the deposition rates but increasing the quality of the nacre (Shirai, 1970). In tropical countries, with high temperatures prevailing throughout the year, nacre secretion is faster (Alagarswami, 1991). Even with advantages like fast nacre production and a sound hatchery technology for seed production, marine pearl culture has not become popular in India as it has in other countries which started pearl culture programs much later than India (Appukuttan et al., 2000). One of the reasons identified for this low pace of technology adoption has been the small size of the pearls produced (Victor et al., 2003).

In India, P. fucata has a natural distribution only in the Gulf of Mannar (in the Bay of Bengal) along the southeast coast and in the Gulf of Kutch (in the Arabian Sea) along the northwest coast of India. The low shell thickness of $P$. fucata oysters grown along the Indian east coast has discouraged attempts to produce pearls larger than $5 \mathrm{~mm}$. Consequent to the successful transplantation of P. fucata oysters from the Gulf of Mannar to the southeastern Arabian Sea (southwest coast of India) under a World Bank aided project, it was possible to develop a stock of $P$. fucata with higher shell thickness (Mohamed et al., 2006). One of the latest designer trends in cultured pearl industry is the preference for large Akoya pearls preferably above $6 \mathrm{~mm}$. The inclination for larger pearls is so pronounced that major Akoya pearl producers have targeted production exclusively for 6 to $6.5 \mathrm{~mm}$ and 7 to $7.5 \mathrm{~mm}$ pearls and attempts are also made to produce even larger $(\sim 10 \mathrm{~mm})$ pearls.

The main objective of this study was to test the feasibility of production of large pearls of 6 to $8 \mathrm{~mm}$ in the P. fucata along the Indian southwest coast. Along with this, mortality and retention rates of implanted oysters, rate of nacre production, thickness of nacre deposited, quality and type of pearls produced and effect of hydrographic variations on the mortality of implanted oysters were also studied.

\section{Materials and methods}

The study was initiated in October 2001 in Kollam Bay, a man-made semi-enclosed bay of $6.6 \mathrm{~km}^{2}\left(8.8^{\circ} \mathrm{N}\right.$; $76.5^{\circ} \mathrm{E}$ ), along the southwest coast of India in the Arabian Sea. Pearl oysters transplanted as spat from the southeast coast of India and reared to adult size were used in the study. These oysters were stocked in cages which were suspended from two $5 \times 5$ m wooden rafts kept afloat by 4 FRP (Fibre Reinforced Plastic) coated rectangular barrels and moored at a depth of $5 \mathrm{~m}$ with four $25 \mathrm{~kg}$ Danforth anchors each.

\subsection{Experimental design}

As a preparation for implantation, the healthy oysters with good growth processes were selected and cleaned off fouling animals one week prior to implantation. Following this, at the time of initiation of implantation, 1500 oysters having shell thickness greater than $20 \mathrm{~mm}$ 
and without any shell damage were placed in tanks with clean seawater with their hinge down. Among these, oysters which responded by opening their valves were selected for implantation. The oysters used were about a year old and had an average height (dorso-ventral measurement) of $61.7 \pm 7.6 \mathrm{~mm}$ ( \pm standard deviation), a thickness of $25.1 \pm 2.4 \mathrm{~mm}$ and total weight $35.6 \pm 13.2 \mathrm{~g}$.

All implantations (seeding) were done in the morning hours to reduce stress due to increased temperature. The oysters were implanted with one shell bead nuclei (Fukai Shell Nucleus Factory, Hong Kong) of either $6 \mathrm{~mm}(6.09 \pm 0.13 \mathrm{~mm})$ or $5 \mathrm{~mm}(5.48 \pm$ $0.2 \mathrm{~mm}$ ) diameter by the surgical method described by Alagarswami (1987). Implanting was carried out by two women technicians with more than 10 years experience and they were assumed to have equal skills. One year old healthy oysters were used for 'donor' mantle (graft tissue) irrespective of shell colour. The sizes of the grafts were between $2-3 \mathrm{~mm}^{2}$ and a total of 37 oysters were sacrificed for seeding. After seeding the oysters were placed in filtered seawater for $2-3 \mathrm{~h}$ before being stocked in the farms. The seeded oysters were stocked at the rate of 19-30 oysters (mean 25 oysters) per square lantern cage of $30 \times 30 \mathrm{~cm}$ made of aluminum frame and nylon net with $10 \mathrm{~mm}$ webbing. A total of 706 oysters were seeded, 311 with $5 \mathrm{~mm}, 395$ with $6 \mathrm{~mm}$ nuclei and stocked in 30 cages (these were used to evaluate pearl production and quality of pearls as detailed in Section 2.4). For collecting the rejected nuclei/pearls, the cages were covered at the bottom with 'catch bags' (small meshed nets).

\subsection{Estimation of survival and mortality}

For studying the monthly mortality and pearl production rates, 125 pearl oysters from each nucleus size group, were reared separately in tagged cages. For each size group of nuclei 5 replicates ( 5 cages $\times 25$ oysters) were maintained. As controls, unseeded oysters of similar sizes and number were maintained in separate cages. These tagged cages were checked every month during the experimental period of 317 days. During each sampling, the number of dead oysters in the experimental and control cages was noted. The 'vomits' (rejected nucleus) were collected from the catch bag and the presence or absence of nacre coating, the uniformity of nacre coating on the nucleus, the presence and number of teats (projections; see Norton et al., 2000 for details) on the pearls were also noted. Fouling organisms on the oysters were removed periodically, the cages cleaned of encrustations and silt, and replaced with fresh cages if the sides were damaged or torn.

For comparing the effect of nucleus size on the mortality of oysters, based on the number of dead oysters in the experimental and control cages, the monthly mortality rate $(Z)$ was calculated as (Caddy and Defoe, 2003)

$Z=-L N(S)$

where, $L N(S)$ is the natural log of survival rate, determined as

$S=\frac{N_{t+1}}{N_{t}}$

where, $N_{t}$ is the initial number of oysters and $N_{t+1}$ is the number surviving after time $t$. The $Z$ value obtained for each treatment was compared by one way ANOVA and in case of significant differences, means were compared by post-hoc Duncan's test using SPSS software (ver. 8.0).

Table 1

Mean instantaneous mortality rate $(Z) \pm$ SD of implanted oysters and control during different sampling months

\begin{tabular}{|c|c|c|c|c|}
\hline \multirow{2}{*}{$\begin{array}{l}\text { Days of } \\
\text { culture }\end{array}$} & \multicolumn{3}{|c|}{ Mortality rate $(Z) \pm \mathrm{SD}$ in implanted oysters and control } & \multirow{2}{*}{$\begin{array}{l}P \text { value and } \\
\text { significance }(*)\end{array}$} \\
\hline & $6 \mathrm{~mm}$ nucleus & $5 \mathrm{~mm}$ nucleus & Control & \\
\hline 31 (Nov) & $0.173 \pm 0.022$ & $0.107 \pm 0.025$ & $0.042 \pm 0.041$ & $0.023^{*}$ \\
\hline 61 (Dec) & $0.078 \pm 0.027$ & $0.096 \pm 0.020$ & $0.039 \pm 0.020$ & 0.416 \\
\hline 89 (Jan) & $0.032 \pm 0.022$ & $0.039 \pm 0.023$ & $0.060 \pm 0.030$ & 0.782 \\
\hline 133 (Feb) & $0.031 \pm 0.024$ & $0.040 \pm 0.022$ & $0.018 \pm 0.018$ & 0.85 \\
\hline 164 (Mar) & $0.045 \pm 0.017$ & $0.072 \pm 0.031$ & $0.000 \pm 0.000$ & 0.230 \\
\hline 197 (Apr) & $0.073 \pm 0.028$ & $0.097 \pm 0.014$ & $0.000 \pm 0.000$ & 0.078 \\
\hline 228 (May) & $0.144 \pm 0.023$ & $0.069 \pm 0.018$ & $0.061 \pm 0.060$ & 0.095 \\
\hline 254 (Jun) & $0.110 \pm 0.049$ & $0.097 \pm 0.031$ & $0.077 \pm 0.005$ & 0.891 \\
\hline 278 (Jul) & $0.043 \pm 0.034$ & $0.058 \pm 0.039$ & $0.051 \pm 0.025$ & 0.954 \\
\hline 317 (Aug) & $0.024 \pm 0.016$ & $0.052 \pm 0.034$ & $0.000 \pm 0.000$ & 0.442 \\
\hline
\end{tabular}

Asterisk indicates significant differences at $5 \%$ level. 


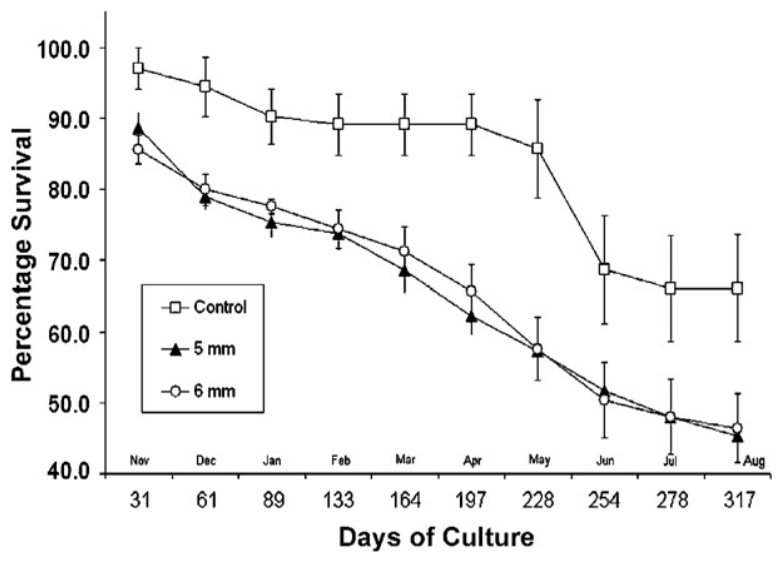

Fig. 1. Percentage survival in 5 and $6 \mathrm{~mm}$ implanted $P$. fucata oysters and control during the experimental period. Vertical bars indicate standard deviations.

\subsection{Effect of environmental variations on mortality rates}

The monthly hydrographic variations at the farm site were studied by taking water samples from the farm site at a depth of $1.5 \mathrm{~m}$ using 101 Niskin Bottles. Water temperature, salinity and $\mathrm{pH}$ were recorded. Photosynthetic pigments (Chlorophyll $a, b$ and $c$ ), total suspended solids (TSS, $\mathrm{mg} \mathrm{L}^{-1}$ ) and nutrients viz., nitrate, nitrite and phosphate were determined using methods outlined in Strickland and Parsons (1972). Rainfall data were collected from the Indian Meteorology Department. The correlation between temporal changes in hydrological parameters at the farm site at Kollam Bay and the monthly $Z$ values were analyzed by means of Spearman correlation using SPSS (ver.8.0) software.

\subsection{Pearl production and quality of pearls}

The pearls were harvested in August 2002 after 317 days of rearing. During the harvest, the oysters were sacrificed and the pearls removed. Each pearl was checked and the types of pearls formed such as baroques and spherical or Akoya pearls in each cage were noted. Further classification of the Akoya pearls was done based on the grading criteria given by Shirai (1970) into good quality (Grade A: flawless, one flaw, small flaws, small stain, pink silver or light cream; Grade B: fairly large flaws, stains, cream colour and Grade C: off shape, badly coated, pock marked, half good and half bad) and trash. Further, quality pearls (similar to Grade A) having an interesting but irregular and symmetrical shapes were identified as baroques. These were treated separately as they have high luster and thicker nacre and therefore command a good price. The diameters of the pearls were measured using digital Vernier calipers (Mikito ${ }^{\circledR}$ ) to the nearest $0.01 \mathrm{~mm}$. For calculating the percentage of different grades and types of pearls produced, pearls from all implanted oysters were pooled.

\section{Results}

\subsection{Survival of implanted oysters}

The mortality rates were highest, $0.173 \pm 0.22$ for the $6 \mathrm{~mm}$ nucleus implanted oysters followed by $5 \mathrm{~mm}$ nucleus implanted oysters at $0.107 \pm 0.025$ during the first 30 days after implantation (Table 1). These values were significantly different $(P<0.05)$ from the mortality rate of the control oysters $(0.042 \pm 0.04)$. After this initial mortality, the monthly $Z$ values were low in general and were nil for the control oysters during March, April and August. The overall survival of $5 \mathrm{~mm}$ nucleus implanted oysters decreased from $88.7 \%$ in the first month after implantation to $45.4 \%$ at the time of harvest (Fig. 1). The $6 \mathrm{~mm}$ nucleus implanted oysters also followed a similar trend with $85.6 \%$ survival

Table 2

Percentage pearl production in survivors and in total implants, by nucleus diameter and by cage

\begin{tabular}{|c|c|c|c|c|c|c|}
\hline Treatment & Cage no. & Total implanted & Total surviving & Number of pearls produced & Retention rate in survivors $(\%)$ & Retention rate $(\%)$ \\
\hline \multirow[t]{6}{*}{$5 \mathrm{~mm}$ implants } & 6 & 19 & 7 & 3 & 42.9 & 16 \\
\hline & 10 & 30 & 15 & 5 & 33.3 & 17 \\
\hline & 19 & 26 & 13 & 8 & 61.5 & 31 \\
\hline & 25 & 25 & 10 & 5 & 50.0 & 20 \\
\hline & 27 & 25 & 12 & 5 & 41.7 & 20 \\
\hline & Total $/$ mean & 125 & 57 & 26 & 45.9 & 21 \\
\hline \multirow[t]{6}{*}{$6 \mathrm{~mm}$ implants } & 1 & 25 & 10 & 6 & 60.0 & 24 \\
\hline & 12 & 25 & 11 & 5 & 45.5 & 20 \\
\hline & 16 & 25 & 13 & 4 & 30.8 & 16 \\
\hline & 22 & 25 & 16 & 8 & 50.0 & 32 \\
\hline & 24 & 25 & 12 & 7 & 58.3 & 28 \\
\hline & Total/mean & 125 & 62 & 30 & 48.9 & 24 \\
\hline
\end{tabular}


initially and $46.4 \%$ survival at the end. The control oysters had high survival (85.7\%) until May (228 days) but thereafter decreased and reached $68.7 \%$ and $66.1 \%$ during June and July respectively without any further mortality. For all the treatments, the mortality rates were slightly higher during May (pre-monsoon) and June (monsoon) months.

\subsection{Nucleus retention rates}

The percentage pearl production (retention rate) was an average of 21 and $24 \%$ of the total for the $5 \mathrm{~mm}$ and $6 \mathrm{~mm}$ nucleus implanted oysters respectively (Table 2 ). However when the retention rates are based on the surviving oysters, it ranged from 33 to $61 \%$ (average 45.9 for $5 \mathrm{~mm}$ ) and 31 to $60 \%$ (average $48.9 \%$ for $6 \mathrm{~mm})$.

\subsection{Quality of pearls}

The largest pearl produced in this experimental trial had a diameter of $7.78 \mathrm{~mm}$ with a nacre thickness of $1.74 \mathrm{~mm}$. The average sizes of the $6 \mathrm{~mm}$ and $5 \mathrm{~mm}$ nucleated pearls were $7.24 \pm 0.382 \mathrm{~mm}$ and $6.35 \pm$ $0.172 \mathrm{~mm}$ respectively. The average nacre coatings were $1.23 \pm 0.38 \mathrm{~mm}$ and $0.87 \pm 0.172 \mathrm{~mm}$ for 6 and $5 \mathrm{~mm}$ nuclei respectively during the 317 days of culture. Based on this, the nacre deposition rates on the nuclei were found to be $4.0 \pm 1.0 \mu \mathrm{m} \mathrm{day}^{-1}$ and $3.0 \pm 1.0 \mu \mathrm{m}$ day $^{-1}$ for 6 and $5 \mathrm{~mm}$ nuclei respectively (Table 3 ).

Of the 91 pearls harvested in August 2002, 38.5\% were A-grade, $19.8 \%$ B-grade, $25.3 \% \mathrm{C}$-grade, $6.5 \%$ baroques and $9.9 \%$ rejects or trash (Table 4 ). Of the spherical pearls, two were ringed. Among the rejects, 2

Table 3

Comparison of thickness of nacre coating in P. fucata in other areas and present study

\begin{tabular}{lllll}
\hline Study & $\begin{array}{l}\text { Nucleus } \\
\text { diameter } \\
(\mathrm{mm})\end{array}$ & $\begin{array}{l}\text { Average } \\
\text { thickness of } \\
\text { nacre }(\mathrm{mm})\end{array}$ & $\begin{array}{l}\text { Duration } \\
\text { in years }\end{array}$ & $\begin{array}{l}\text { Coating } \\
\text { per day } \\
(\mu \mathrm{m})\end{array}$ \\
\hline Japan, Cahn & 3.05 & 0.32 & 2.0 & 0.4 \\
$\quad(1949)$ & 4.10 & 0.38 & 2.5 & 0.4 \\
& 6.10 & 0.44 & 3.0 & 0.4 \\
India, Alagarswami & 7.90 & 0.50 & 3.5 & 0.4 \\
$\quad$ (1975) & 4.00 & 0.32 & 0.5 & 2.0 \\
& 5.81 & 0.31 & 0.4 & 2.0 \\
India, Dharmaraj & 3.02 & 0.85 & 0.4 & 2.0 \\
and Sukumaran & 4.24 & 0.96 & 1.0 & 2.0 \\
$\quad$ (2003a) & 5.14 & 0.62 & 1.0 & 3.0 \\
Present study & 5.48 & 0.87 & 0.8 & 3.0 \\
& 6.04 & 1.23 & 0.8 & 4.0 \\
\hline
\end{tabular}

Table 4

Number of pearls obtained during harvest and pre-harvest according to the grade classification of Shirai (1970)

\begin{tabular}{lrrrrrr}
\hline Period & \multicolumn{6}{l}{ Pearl grading } \\
\cline { 2 - 7 } & A & B & \multicolumn{1}{c}{ C } & Baroque & Deformed/trash & Total \\
\hline Pre-harvest & 1 & 23 & 3 & 4 & 9 & 40 \\
Harvest & 35 & 18 & 23 & 6 & 9 & 91 \\
Total & 36 & 41 & 26 & 10 & 18 & 131 \\
\hline
\end{tabular}

were plain nucleus without any coating even after a period of 317 days. Some of the spherical pearls had small projections, either on one side or on diametrically opposite sides. The rejects having projections were scrutinized and it was found that they had dark dried tissues inside.

Prior to harvest, during the period March to June, 40 pearls mostly with nacre coating including a few (9 pearls; 22.5\%) without coating, were obtained from dead implanted oysters. Of these, only $2.5 \%$ were A-grade, while majority $57.5 \%$ were B-grade, $7.5 \%$ $\mathrm{C}$-grade and $10 \%$ of the pearls were baroque (Table 4 ). Of the total 131 pearls obtained from harvest and preharvest, $27.6 \%$ were A-grade, 31.3\% B-grade, 19.8\% C-grade, $7.6 \%$ baroques and $13.7 \%$ rejects or trash (Table 4).

\subsection{Environmental variations}

The variation in selected environmental parameters, like mean monthly TSS and temperature is shown in Fig. 2. The temperature increases steadily from November (winter) to April (summer) and then decreases to a low in July coinciding with the southwest monsoon. The TSS values show a peak in June coinciding with southwest monsoon and river runoff. Among the environmental parameters monitored, the total suspended solids

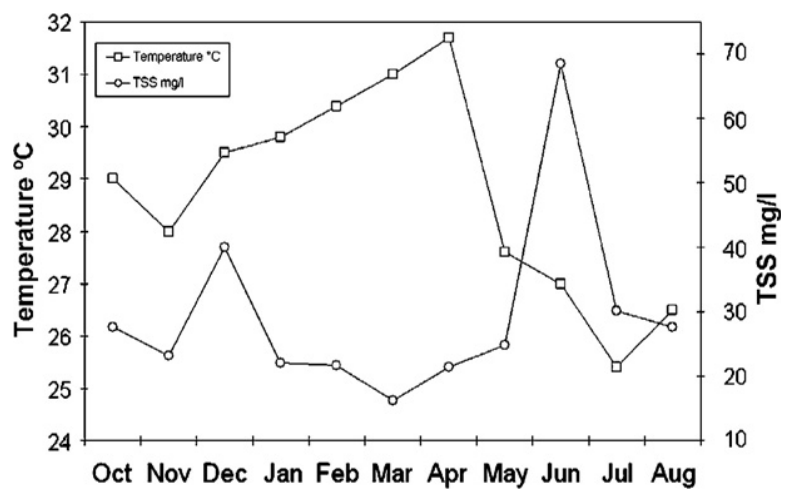

Fig. 2. Variation in mean monthly temperature and total suspended solids (TSS) at the farm site in Kollam Bay during the culture period. 
Table 5

Spearman correlation of environmental variables and monthly mortality rate

\begin{tabular}{|c|c|c|c|c|}
\hline $\begin{array}{l}\text { S } \\
\text { No. }\end{array}$ & $\begin{array}{l}\text { Environmental } \\
\text { variables }\end{array}$ & $\begin{array}{l}\text { Annual } \\
\text { average }\end{array}$ & $\begin{array}{l}\text { Correlation with } \\
\text { monthly } Z \text { values } \\
\text { of implanted } \\
\text { oysters }\end{array}$ & $\begin{array}{l}\text { Correlation with } \\
\text { other } \\
\text { environmental } \\
\text { variables }\end{array}$ \\
\hline 1 & Rainfall (cm) & 135.00 & - & $\mathrm{pH}\left(-0.76^{* *}\right)$ \\
\hline 2 & Salinity (ppt) & 33.00 & - & - \\
\hline 3 & $\mathrm{DO}(\mathrm{mg} / \mathrm{l})$ & 4.50 & - & $\begin{array}{l}\text { Ammonia } \\
\left(-0.71^{*}\right)\end{array}$ \\
\hline 4 & GP (mgC/1/Day) & 1.49 & - & $\mathrm{NP}(0.92 * *)$ \\
\hline 5 & NP (mgC/1/Day) & 0.97 & - & - \\
\hline 6 & TSS (mg/l) & 29.27 & $0.88^{*}$ & $\begin{array}{l}\text { Nitrate } \\
\left(0.91^{* *}\right)\end{array}$ \\
\hline 7 & Temperature ${ }^{\circ} \mathrm{C}$ & 28.69 & - & $\begin{array}{l}\text { Chl } a\left(0.84^{* *}\right) \\
\text { Chl } c\left(0.73^{*}\right)\end{array}$ \\
\hline 8 & $\mathrm{pH}$ & 7.24 & - & - \\
\hline 9 & $\begin{array}{l}\text { Ammonia } \\
\left(\mu \mathrm{g} \text { at } \mathrm{NH}_{3}-\mathrm{N} / \mathrm{l}\right)\end{array}$ & 4.49 & - & - \\
\hline 10 & $\begin{array}{l}\text { Phosphate } \\
\left(\mu \mathrm{g} \text { at } \mathrm{PO}_{4}-\mathrm{P} / \mathrm{l}\right)\end{array}$ & 23.01 & - & - \\
\hline 11 & $\begin{array}{l}\text { Nitrate } \\
\left(\mu \mathrm{g} \text { at } \mathrm{NO}_{3}-\mathrm{N} / \mathrm{l}\right)\end{array}$ & 4.25 & - & - \\
\hline 12 & $\begin{array}{l}\text { Nitrite } \\
\left(\mu \mathrm{g} \text { at } \mathrm{NO}_{2}-\mathrm{N} / \mathrm{l}\right)\end{array}$ & 2.50 & - & $\begin{array}{l}\text { Phosphate } \\
\left(0.91^{* *}\right)\end{array}$ \\
\hline 13 & $\begin{array}{l}\text { Chlorophyll } a \\
(\mu \mathrm{g} / \mathrm{l})\end{array}$ & 0.64 & - & - \\
\hline 14 & $\begin{array}{l}\text { Chlorophyll } b \\
(\mu \mathrm{g} / \mathrm{l})\end{array}$ & 0.32 & - & - \\
\hline 15 & $\begin{array}{l}\text { Chlorophyll } c \\
(\mu \mathrm{g} / \mathrm{l})\end{array}$ & 0.71 & - & - \\
\hline
\end{tabular}

*Significant at $5 \%$ level — two tailed; **Significant at $1 \%$ level two tailed.

(TSS) in the water were found to be positively correlated $(P<0.05)$ to the monthly mortality rate of the implanted oysters. Though there were positive and negative correlations between environmental parameters, (Table 5) these were not correlated with the survival of oysters during the study period.

\section{Discussion}

The survival rates obtained in the trials were better than that observed in P. fucata oysters from the east coast of India (Alagarswami, 1987; Dharmaraj and Sukumaran, 2003a). The high mortality during the initial phase may be due to several factors such as low pre-operative care (Taylor and Knauer, 2002) and low post-operative care (Meng and Xing, 1991). This was the first attempt by the technicians who were adept at implanting 3-4 $\mathrm{mm}$ nuclei rather than larger nucleus. Moreover, only minimal post-operative care was provided during the present experiment as the oysters could not be placed in running seawater and no antibiotics were given to assist in healing the wound. Loss of body fluids has been observed in implanted oysters and as much as one third of the haemolymph can be lost from the incision made to allow insertion of the mantle tissue and nucleus (Lintilhac, 1987). Though oysters have the ability to heal wounds quickly (AcostaSalmon and Southgate, 2006), this stress would result in mortality (Friedman, 1999).

Dharmaraj and Sukumaran (2003b) found that the survival of implanted oysters varied depending on the size of the oysters with highest survival, $51.1 \%$ in $41-50 \mathrm{~mm}$ oysters, followed by $42.6 \%$ in $51-60 \mathrm{~mm}$ oysters and $25 \%$ in $61-70 \mathrm{~mm}$ oysters. The survival obtained after a post-operative period of 352 days in 61-70 mm oysters was much lower than that obtained in the present study.

In P. margaritifera, after grafting (seeding), approximately $10 \%$ of the oysters suffer mortality and a further 20\% reject the nucleus (Ellis and Haws, 1999). They inferred that numbers greater than this may indicate poor technical skill or onset of disease. In the present experiment the survival rate was a little more than $45 \%$ for implanted oysters, while that for the control nonimplanted oysters it was $66 \%$. Therefore, about $20 \%$ of the mortality might have occurred due to the surgical procedure for implantation. High mortality in both implanted and control oysters was observed in the month of May-June due to the onset of the southwest monsoon and the resulting high TSS values (significant positive correlation with mortality). Post seeding mortality in other studies has been found to be due to the outbreak of unidentified disease (Cabral, 1992) with an average retention rate of $40 \%$ (Coeroli and Mizuno, 1985; Salomon and Roudnitska, 1986; Lintilhac, 1987). Retention of nucleus in P. margaritifera in Solomon Islands has been found to be $66.25 \%$ (Friedman, 1999) while in Cook islands, retention rates of oysters have been found to range from 45 to $90 \%$ depending on the farm and the atoll (Friedman, 1999). In Japan, for P. margaritifera, the retention rate for hatchery reared oysters is reportedly around $50 \%$ (Kakazu, 1991).

In India, the retention rates using small nucleus (3 to $4 \mathrm{~mm}$ ) have been found to vary in different trials conducted earlier. It was 25\% (Appukuttan et al., 2000) when the farms were located in a deeper region and low, ranging between 11.3 to $41.36 \%$ of surviving oysters which is about 8.8 to $27 \%$ of the initial implanted oysters when the farms were set very near to the shore. The comparatively low performance in the latter instance has been attributed to the shallow depth of the pearl farm (Victor et al., 2003). A decline in the condition of the oysters and therefore pearl production 
in shallow areas was thought by Chellam et al. (1987) to be due to the prevailing high silt loads. Along the Indian west coast, in an earlier experiment on pearl production using 3 to $4 \mathrm{~mm}$ nucleus, at a site about $100 \mathrm{~km}$ north of the present experimental farm, the retention rate among survivors was 33\% (Velayudhan et al., 1999). Along the southeast coast of India, Dharmaraj and Sukumaran (2003b) have found that in different size groups of oysters implanted with $5.14 \mathrm{~mm}$ nucleus, the retention rate in the surviving oysters ranged between $33.3 \%$ in small sized oysters to $55 \%$ in large oysters with higher mortality for larger oysters. The retention rates obtained in the present study ranged from 45 to $48 \%$ with higher survival rates, indicating that the Kollam Bay may be a potential location for production of 6-8 $\mathrm{mm}$ Akoya pearls.

Although the luster, shine, orient, and inclusions are very important in determining the value of an Akoya pearl (Landman et al., 2001), these are influenced by the thickness of nacre and a quality nacre should be at least $0.4-0.5 \mathrm{~mm}$ thick, which would have at least 1000 layers of nacre on it (Hollyer, 1984). In the present study it was possible to obtain relatively thick nacre in a very short period, the deposition rate being about 9 times higher than that observed in Japanese waters and 2.2 to 2.3 times more than along the Indian southeast coast (Table 3). The recommended period for harvest of Japanese Akoya pearls is 16 to 24 months (Shirai, 1970), but along the Indian southwest coast, the growout period can be between 6 to 10 months since the nacre deposition rate is higher. Though it is well known that slower nacre deposition and therefore, thin nacre layers results in better pearl quality (Gervis and Sims, 1992), in tropical conditions as in the present study the ambient temperatures are above $25^{\circ} \mathrm{C}$ and the difference between minimum and maximum is hardly $6{ }^{\circ} \mathrm{C}$. It is also reported that lower temperatures result in better pearl luster and harvests are usually timed to this (Gervis and Sims, 1992) and therefore care was taken in the present study to harvest the pearls when the water temperatures were low.

The percentages of A-grade pearls were higher in the present study compared to other reports on pearl production in Indian waters (Alagarswami, 1987; Victor et al., 2003; Dharmaraj and Sukumaran, 2003b). Ellis and Haws (1999) have evaluated the economic returns of black pearl farming and observed that on an average about 5 to $10 \%$ of the harvested pearls will be graded A and $95 \%$ of the income from the pearl farm will be derived from this.

Among the rejects it was observed that the coating on the nucleus was not uniform and some of the projections on the pearls were dried tissue, few partly calcified, while some portions of the projections were mainly increased deposition of nacre. In P. margaritifera, such calcified projections were called tails and were found to contain dead inflammatory cells (Norton et al., 2000). Such flaws are common and it has been found that quality of the graft tissue, pre-operative conditioning and post-operative care influence the quality of the pearl formed (Aoki, 1961; Alagarswami, 1987; Meng and Xing, 1991; Gervis and Sims, 1992; Friedman, 1999). The percentage of deformed and trash pearls in the present study could be reduced by improving pre- and post-operative care. Since a positive correlation was observed between the TSS and mortality of implanted oysters, locations and periods of high TSS can be avoided to increase survival of the implanted oysters.

Size preferences of Akoya pearls in the global market have been changing during the past decade with increased preference for larger pearls. The results of the present study indicate that there is good potential to produce large Akoya pearls in the Indian pearl oyster similar to those cultured in Japan and China. With better pre and post-operative care it will be possible to increase the retention rates in implanted oysters.

\section{Acknowledgements}

The authors are grateful to the Director, Central Marine Fisheries Research Institute (CMFRI), Cochin for facilities and encouragement. They are thankful to the technical and supporting staff and research scholars of the Molluscan Fisheries Division for technical help. Comments by three anonymous referees greatly helped to improve the manuscript for which the authors are obliged. The study was funded by the National Agricultural Technology Project (NATP) of the World Bank (Grant No. 2090000004) which is gratefully acknowledged.

\section{References}

Acosta-Salmon, H., Southgate, P.C., 2006. Wound healing after excision of mantle tissue from the Akoya pearl oyster Pinctada fucata. Comp. Biochem. Physiol., Part A 143, 264-268.

Alagarswami, K., 1975. Preliminary study on the growth of cultured pearls. Indian J. Fish. 22, 300-303.

Alagarswami, K., 1987. Cultured pearls - technology of cultured pearl production. In: Alagarswami, K. (Ed.), Pearl culture. Bull. Cent. Mar. Fish. Res. Inst., vol. 39. Central Marine Fisheries Research Institute, Cochin, India, pp. 98-106.

Alagarswami, K., 1991. Production of Cultured Pearls. Indian Council of Agricultural Research, New Delhi, India. 112 pp.

Aoki, S., 1961. Some experiments on the nuclear insertion in pearl culture of the oyster (Pinctada martensii). V. Pearl sac formation in 
the material with a space between inserted nucleus and adjacent tissue. Bull. Natl. Pearl Res. Lab. 6, 647-656.

Appukuttan, K.K., Kripa, V., Velayudhan, T.S., Mohamed, K.S., Victor, A.C.C., Kuriakose, P.S., Laxmilatha, P., Muthiah, P., 2000. Bivalve Mariculture in India. A Success Story in Coastal Ecosystem Development. Asia Pacific Association of Agricultural Research Institutions, FAO. (APAARI Publication 2000/1), 55 pp.

Cabral, P., 1992. First harvest of hatchery pearls in French Polynesia. South Pacific Commission, Pearl Oyster Information Bulletin, vol. 5. $15 \mathrm{pp}$.

Caddy, J.F., Defoe, O., 2003. Enhancing or restoring the productivity of natural population of shellfish and other marine invertebrate resources. FAO Fish. Tech. Pap. 448 168pp.

Cahn, A., 1949. Pearl culture in Japan. United States Dept. Interior Fish Wildlife Service. Fish Leaflet, 357, 1-91.

Chellam, A., Velayudhan, T.S., Victor, A.C.C., 1987. Pearl oyster farming. In: Alagarswami, K. (Ed.), Pearl culture. Bull. Cent. Mar. Fish. Res. Inst., vol. 39. Central Marine Fisheries Research Institute, Cochin, India, pp. 72-77.

Coeroli, M., Mizuno, K., 1985. Study of different factors having an influence upon the pearl production of the black lip pearl oyster. Proc. 5th Coral Reef Congress, Tahiti, vol. 5, pp. 551-556.

Dharmaraj, S., Sukumaran, N., 2003a. Role of post operative culture period on cultured pearl production in the Indian pearl oyster Pinctada fucata (Gould). Abstracts of the First Indian Pearl Congress and Exposition. Central Marine Fisheries Research Institute, Cochin, India, p. 57. 5-8 February 2003.

Dharmaraj, S., Sukumaran, N., 2003b. Effect of oyster size on cultured pearl production in the Indian pearl oyster Pinctada fucata (Gould). Abstracts of the First Indian Pearl Congress and Exposition. Central Marine Fisheries Research Institute, Cochin, India, p. 58. 5-8 February 2003.

Ellis, S., Haws, M., 1999. Producing pearls using the black-lip pearl oyster (Pinctada margaritifera). Aquaculture Information Sheet, Center for Tropical and Subtropical Aquaculture, pp. 73-76.

Friedman, K.M., 1999. Seeding of black-lip pearl oysters P. margaritifera (L.) collected from wild spat and wild adults from open reef systems of Solomon Islands. In: Lee, C.L., Harvey, D.C. (Eds.), Proc. World Aquaculture Conference. Tropical Aquaculture in the Kimberley Broome, May 27-29, 1990, pp. 63-72.

Gervis, M.H., Sims, N.A., 1992. The biology and culture of pearl oysters (Bivalvia: Pteridae) ICLARM Studies and Reviews. 21, Overseas Development Administration, UK and ICLARM, Manila. 49 pp.

Guo, X., Ford, S.E., Zhang, F., 1999. Molluscan aquaculture in China. J. Shellfish. Res. 18, 19-31.

Hollyer, J., 1984. Pearls - jewels of the sea. Infofish Mark. Dig. 5, $32-34$.

Jagadis, I., Ignatius, B., Ilangovan, K., Victor, A.C.C., Chellam, A., Rani, V., 2003. Pearl production in Pinctada fucata under two culture systems in the inshore waters of Mandapam, Gulf of Mannar. Abstracts of the First Indian Pearl Congress and Exposition. Central Marine Fisheries Research Institute, Cochin, India, p. 70. 5-8 February 2003.

James, P.S.B.R., Narasimham, K.A., 1994. Saltwater pearl culture in India: an update. Aquac. Mag. 41-49 July/August.
Kakazu, K., 1991. Mariculture of molluscs: black lip pearl oyster (Pinctada margaritifera). In: Shokia, T. (Ed.), Aquaculture in Tropical Areas. Midori Shobo, Tokyo, pp. 236-242.

Landman, N.H., Mikkelsen, P.M., Bieler, R., Bronson, B., 2001. Pearls: A natural history. Harry and Abrams, Inc., New York, USA. $232 \mathrm{pp}$.

Lintilhac, J., 1987. Black Pearls of Tahiti. Royal Tahitian Black Pearl Book, Papeete, Tahiti. 53 pp.

Meng, Z., Xing, K., 1991. The effects of various factors on the nucleus insertion of the black-lipped oysters Pinctada margaritifera Linnaeus. Oceanologia et Limnologia Sinica 22, 44-45.

Mohamed, K.S., Kripa, V., Velayudhan, T.S., Appukuttan, K.K., 2006. Growth and biometric relationships of the pearl oyster Pinctada fucata (Gould) on transplanting from the Gulf of Mannar to the Arabian Sea. Aquac. Res. 37, 725-741.

Norton, J.H., Dashorst, M., Lansky, T.M., Mayer, R.J., 1996. An evaluation of some relaxants for use with pearl oysters. Aquaculture $144,39-52$.

Norton, J.H., Lucas, J.S., Turner, I., Mayer, R.J., Newham, R., 2000. Approaches to improve cultured pearl formation in Pinctada margaritifera through use of relaxation, antiseptic application and incision closure during bead insertion. Aquaculture 184, 1-17.

Salomon, P., Roudnitska, M., 1986. Tahiti, The Magic of Black Pearl. Tahiti Pearls, SNC WAN et Cie. 221 pp.

Shirai, S., 1970. The Story of Pearls. Japan Publications Inc., Japan. $132 \mathrm{pp}$.

Strickland, J.D.H., Parsons, T.R., 1972. A practical handbook of seawater analysis. Bulletin Fisheries Research Board of Canada, vol. 167 , pp. 1-310.

Taylor, J.U., Knauer, J., 2002. Inducing pre-operative condition in silver or gold lipped pearl oysters Pinctada maxima for pearl grafting. Abstracts of the SPC Pearl Oyster Information Bulletin, vol. 15 , p. 30 .

Velayudhan, T.S., Chellam, A., Dharmaraj, S., Victor, A.C.C., Kasim, H.M., 1996. Comparison of growth and shell attributes of four generations of pearl oyster Pinctada fucata (Gould) produced in the hatchery. Indian J. Fish. 43, 69-77.

Velayudhan, T.S., Kripa, V., Alloycious, P.S., 1999. Pearl culture experiment along Kerala coast. In: Modayil, M.J. (Ed.), Proceedings of the Fourth Indian Fisheries Forum, Indian Fisheries Forum, Mangalore, India, pp. 179-181.

Victor, A.C.C., Jagadis, I., Ignatius, B., Chellam, A., 2003. Perspectives and problems of commercial scale pearl culture - an indicative study at Mandapam Camp, Gulf of Mannar. Abstracts of the First Indian Pearl Congress and Exposition. Central Marine Fisheries Research Institute, Cochin, India, pp. 73-75. 5-8 February 2003.

Wada, K.T., 1991. The pearl oyster, Pinctada fucata (Gould) (family Pteriidae). In: Menzel, W. (Ed.), Estuarine and Marine Bivalve Mollusk Culture. CRC Press, Boca Raton, Florida.

Wada, K.T., Kamaru, A., 1996. Colour and weight of pearls produced by grafting the mantle tissue from a selected population for white shell colour of the Japanese pearl oyster, Pinctada fucata martensii (Dunker). Aquaculture 142, 25-32. 